3. Б. Лопсонова, Н. В. Кленина. Управление развитием профессиональной карьеры молодых педагогов ДОО

\author{
Научная статья \\ УДК 378.1:373.2 \\ DOI: $10.18101 / 2307-3330-2021-3-27-31$
}

\title{
УПРАВЛЕНИЕ РАЗВИТИЕМ ПРОФЕССИОНАЛЬНОЙ КАРЬЕРЫ МОЛОДЫХ ПЕДАГОГОВ ДОО
}

\author{
(C) Лопсонова Зинаида Баторовна \\ кандидат педагогических наук, доцент, \\ Бурятский государственный университет имени Доржи Банзарова \\ Россия, 670000, г. Улан-Удэ, ул. Смолина, 24 а \\ Lopsonova@mail.ru \\ (C) Кленина Наталья Владимировна \\ заведующая МБДОУ № 35 «Алые паруса», \\ Россия, 670000, г. Улан-Удэ, ул. Профсоюзная, 7 \\ parusa3535@mail.ru
}

Аннотация. В статье раскрываются особенности управления развитием профессиональной карьеры молодых педагогов дошкольной образовательной организации. Обобщается опыт работы руководителя дошкольной образовательной организации по организации наставничества над молодыми специалистами, мотивации к достижению результатов педагогической деятельности, формированию установок дальнейшего профессионального роста. Рассмотрены сложности вхождения молодого педагога в педагогическую профессию, особенности организации сопровождения на методическом, психолого-педагогическом, управленческом уровнях. Авторы делятся опытом реализации проекта по дуальному образованию с Бурятским республиканским педагогическим колледжем по подготовке специалистов дошкольного образования. Особенностью работы детского сада является творческая образовательная среда, в которой молодые педагоги получают возможность развивать свои профессиональные и надпрофессиональные навыки. Одним из механизмов управленческого подхода является продуманная стратегия развития профессиональной карьеры молодого педагога путем разработки индивидуальной программы профессионального роста.

Ключевые слова: профессиональная карьера, компетенция, наставничество, опыт, молодой специалист, воспитатель, управление, взаимодействие.

\section{Для цитирования}

Лопсонова 3. Б., Кленина Н. В. Управление развитием профессиональной карьеры молодых педагогов ДОО // Вестник Бурятского государственного университета. Образование. Личность. Общество. 2021. № 3. С. 27-31.

В динамично развивающемся современном мире проблема профессионального становления и развития молодых людей становится актуальной. Приоритетной задачей современного образования является достижение высокого качества, которое невозможно рассматривать вне связи продвижения педагога в профессии. Цель данной статьи заключается в изучении подходов к управлению развитием профессиональной карьеры молодых педагогов ДОО.

В стратегии национальной системы учительского роста (НСУР), в Профессиональном стандарте «педагог» отмечается, что профессиональная карьера представляет 
собой не только вертикальную, но и горизонтальную карьеру, предполагающую движение работника организации внутри профессии, становление его как профессионала.

Основной ключевой фигурой, способной решать воспитательные и образовательные задачи дошкольного образования, является педагог, который будет отличаться высоким уровнем профессиональной компетентности. Однако молодой специалист приходит с хорошей теоретической базой подготовки, но недостаточно представляет сложность и многогранность содержания всей педагогической деятельности.

Стратегия управления развитием профессиональной карьеры педагогов включает следующие направления деятельности руководителя ДОО:

1. Работа по повышению образовательного уровня педагогов. В нашем коллективе преобладающее большинство составляют молодые педагоги в возрасте от 20 до 35 лет, в их числе те, кто недавно окончил педагогический колледж, обучается на старших курсах по очной форме, а также получает высшее образование в БГУ. За последние пять лет 5 педагогов нашего ДОУ завершили магистратуру по программе «Менеджмент в образовании» и «Современные технологии филологического образования» (учитель бурятского языка). После обучения в магистратуре они были включены в кадровый резерв комитета образования г. Улан-Удэ и затем назначены на должность руководителя ДОО г. Улан-Удэ. Особенностью кадрового состава нашего детского сада является то, что работают трое молодых педагогов-мужчин: два инструктора по физической культуре и один музыкальный руководитель. Также занятия с детьми по робототехнике проводит молодой педагог дополнительного образования из станции юных техников.

2. Сопровождение процесса адаптации молодых педагогов. Данное направление наставничества включает беседу заведующего ДОО при приеме на работу, ознакомление с должностной инструкцией, условиями труда, правилами внутреннего трудового распорядка и т. д. Вначале молодой специалист проходит стажировку у более опытного педагога, знакомится с детьми, родителями, изучает правила ведения педагогической документации, консультируется у наставника по вопросам организации педагогического процесса. В первое время очень важно давать положительную оценку деятельности начинающего педагога, непосредственную помощь оказывает старший воспитатель детского сада, дает советы, ведет беседы, анализ, рефлексию деятельности. К примеру, мы практикуем среди молодых педагогов написание небольшого эссе о первых шагах вхождения в профессию, что дает нам возможность получить обратную связь и выстроить перспективы развития их профессиональной компетенции. Немаловажное значение имеет определение начинающего педагога в группу с опытным младшим воспитателем, который может оказать ему помощь в организации детей на занятия, проведение режимных моментов, осуществление присмотра и ухода, выстраивании взаимодействия с родителями.

Следует остановиться на трудностях, с которыми встречается молодой педагог в начале своей профессиональной карьеры в ДОО:

- сложность в выстраивании коммуникации с родителями воспитанников. Почему эти трудности возникают? Наши наблюдения показывают, что существует страх, боязнь общения, что свидетельствует о недостаточной сформированности гибких, мягких компетенций (softskills) у начинающего педагога. Иногда родители подавляют 
3. Б. Лопсонова, Н. В. Кленина. Управление развитием профессиональной карьеры молодых педагогов ДОО

своим авторитетом, игнорируют молодого педагога, в таком случае на помощь им приходит администрация ДОО: заведующий, старший воспитатель, а также непосредственно наставник. Мы разбираемся в каждом конкретном случае, советуем, как нужно выстраивать отношения с родителями;

- сложность в организации детей на деятельность, так как группы переукомплектованы, здесь важно четко организовать взаимодействие с младшим воспитателем по осуществлению ухода и присмотра;

- большая загруженность педагога также сказывается на эмоциональном состоянии молодого педагога, 12-часовой режим работы детского сада иногда психологически выматывает молодого педагога, поэтому стараемся выделить выходной на неделе, найти подменного воспитателя;

- низкий уровень заработной платы у начинающего педагога.

Для того чтобы снять такое напряжение и имеющиеся проблемы, оказывается поддержка педагога со стороны руководства, коллектива, оказание психологической помощи, проведение рефлексии, тренингов, приобщение к традициям коллектива, создание условий для неформального общения. Например, организация такого мероприятия, как «Час фитнеса», который проводит инструктор по физической культуре, дает возможность переключиться молодым педагогам, расслабить напряжение и снять усталость.

3. Организация наставничества над молодыми педагогами. В нашем ДОО принято с самого начала трудовой деятельности закрепление педагога-наставника за молодым специалистом. Для этого сначала заполняется дорожная карта наставничества, которая представляет собой программу или план деятельности, отражает интересные формы и методы сотрудничества с молодыми педагогами. Среди них следующие формы: показ открытых занятий и режимных моментов, совместное обсуждение идей по проектированию развивающей среды группы и т. д. В рамках наставничества проводятся тренинги, творческие часы с постановками. Также наставники демонстрируют новшества на авторских мастерских, которые периодически организуются по разным направлениям. Одним из способов является «плавающее» наставничество, как отмечает С. И. Поздеева, «ученик» может сам выбрать себе наставника в зависимости от профессионально-образовательных задач или своего интереса [1]. Также осуществляется планомерная подготовка педагогов к аттестации, через два года на основе полученного и обобщенного опыта педагогической деятельности молодой педагог представляет свое профессиональное портфолио на соответствие должности, затем продвигается дальше.

В течение последних двух лет в образовательном пространстве города работают метапредметные центры по районам как объединения ДОО по различным направлениям деятельности. В наш метапредметный центр входят следующие ДОО г. УланУдэ: № 35, 104, 5, 58, 52, 15. В 2021 г. был проведен слет молодых специалистов в лагере «Родничок» на Верхней Березовке, где молодые педагоги презентовали свои творческие проекты по заранее заданным темам по образовательным областям развития дошкольников. На наш взгляд, состоялся хороший обмен опытом, плодотворное сотрудничество, молодые педагоги сумели себя презентовать, творчески поработать над совместным проектом в команде, познакомиться поближе друг с другом. 
Еще одним новшеством является организация работы с потенциальными педагогическими кадрами. Дело в том, что нами подписано соглашение по дуальному образованию с Бурятским республиканским педагогическим колледжем (БРПК), суть которого заключается в том, что к нам приходят работать воспитателями успешные студенты старших курсов, за ними закрепляем наших опытных наставников, затем они распределяются уже в наш детский сад и приходят к нам уже как дипломированные специалисты. По юридическим требованиям был заключен трехсторонний договор между студентом, ДОО и БРПК, который закрепляет право студентов на выплату всех социальных льгот, на оплату больничных, отпускных, а также стимулирующих выплат.

4. Включение молодых педагогов в инновационную деятельность ДОО. Наше ДОО является пилотной площадкой по обучению детей в трилингвальной среде, дети изучают бурятский и английский языки, определенные результаты в данном направлении развития детей получены и результаты проекта были освещены в публикациях педагогов [2]. Также в пилотном режиме реализуется парциальная программа «От Фребеля до робота: растим юных инженеров», направленная на развитие технического творчества дошкольников. Особенностью реализации данной программы является идея организации культурных практик по развитию технического творчества на основе сетевого взаимодействия. С 2020 г. мы являемся МИП по данному направлению. Следует отметить, что молодой педагог с первого дня погружается в пространство нашего учреждения и попадает в атмосферу инновационного, творческого коллектива. Проводятся семинары, вебинары с ведущими разработчиками программ от «Фребеля до робота: растим будущих инженеров». Они включены в процесс совместного обсуждения проектов: личных, общесадовских, городских, региональных и т. д. В первый год работы молодому педагогу предоставляется возможность сориентироваться в образовательном пространстве ДОО, научиться хорошо выполнять непосредственные обязанности, прийти на помощь, когда это необходимо. Наш детский сад является победителем Федерального гранта «Поддержка семей, имеющих детей» по нацпроекту «Образование», где согласно данному направлению наши педагоги учились оказывать консультативную, методическую, психолого-педагогическую помощь семьям, не охваченным услугами дошкольного образования. Это еще один уровень развития профессиональных компетенций, расширение сферы деятельности благодаря гранту и материальное вознаграждение за труд. Консультации проводились в онлайн-режиме с детьми и их родителями.

Следует отметить, вся экспериментальная и инновационная деятельность направляется научным руководителем ДОО З. Б. Лопсоновой, канд. пед. наук, доцентом кафедры педагогики начального и дошкольного образования БГУ. Результаты деятельности обсуждаются на педсоветах, научно-методических семинарах.

5. Вовлечение педагога в самостоятельный творческий поиск, предполагает формирование способности рефлексировать и самостоятельно управлять своим профессиональным развитием, совершенствовать умение критически оценивать происходящие перемены, ставить цели и добиваться. Немаловажное значение имеет выработка своего индивидуального стиля общения с детьми, родителями и педагогами. 
3. Б. Лопсонова, Н. В. Кленина. Управление развитием профессиональной карьеры молодых педагогов ДОО

Таким образом, нами проводится серьезная и планомерная работа по организации наставничества и управления развитием профессиональной карьеры молодых педагогов.

Литература

1. Поздеева С. И. Наставничество как деятельностное сопровождение молодого специалиста: модели и типы наставничества // Научно-педагогическое обозрение. 2017. № 2(16). С. 87-91. Текст: непосредственный.

2. Опыт проектирования в условиях трилингвальной среды / Н. В. Кленина, З. Б. Лопсонова, М. К. Воробьева [и др.] // Дошкольный мир. 2020. № 3. С. 2-3. Текст: непосредственный.

Статья поступила в редакцию 18.11.2021; одобрена после рецензирования 22.11.2021; принята к публикации 07.12.2021.

\title{
PRESCHOOL EDUCATION YOUNG TEACHERS PROFESSIONAL CAREER DEVELOPMENT MANAGEMENT
}

\section{Zinaida B. Lopsonova}

Candidate of Pedagogical Sciences, associate professor

Dorzhi Banzarov Buryat State University

24 a, Smolina St, Ulan-Ude, 670000 Russia

Lopsonova@mail.ru

\author{
Natalia V. Klenina \\ Head of kindergarden \#35 «Alye parusa» \\ 7 Profsoyuznaya St., Ulan-Ude, 670000 Russia \\ parusa3535@mail.ru
}

The authors reveal the features of managing the development of the professional career of young teachers of a preschool educational institution. The article summarizes the experience of the head of a preschool educational institution in the organization of mentoring young specialists, motivation to achieve the results in pedagogical activity, the formation of attitudes for further professional growth. The difficulties of the entry of a young teacher into the teaching profession, the peculiarities of methodological, psychological, pedagogical, managerial support are considered. The authors share their experience of implementing a project on dual education with Buryat Republican Pedagogical College for the training of preschool education specialists. A feature of the kindergarten is a creative educational environment in which young teachers have the opportunity to develop their professional and supra-professional skills. One of the mechanisms of the managerial approach is a wellthought-out strategy for the development of a young teacher's professional career by developing an individual professional growth program.

Keywords: professional career, competence, mentoring, experience, young specialist, educator, management, interaction.

The article was submitted 18.11.2021; approved after reviewing 22.11.2021; accepted for publication 07.12.2021. 